\title{
PENGEMBANGBIAKAN ASEKSUAL TERIPANG KELING (Holothuria atra) DI KAMPUNG MANYAIFUN, RAJA AMPAT, PAPUA BARAT
}

\author{
Afandi Saputra*), Endang Gunaisah*, Fabian Ardianta*), dan Septyan Andriyanto** \\ *) Program Studi Teknologi Budidaya Perikanan, Akademi Perikanan Sorong \\ Jl. Kapitan Pattimura, Tanjung Kasuari, Suprau, Kota Sorong, Papua Barat 98401 \\ E-mail: afandi.saputra@yahoo.co.id \\ **) Pusat Penelitian dan Pengembangan Perikanan Budidaya \\ Jl. Ragunan 20, Pasar Minggu, Jakarta Selatan 12540
}

\begin{abstract}
ABSTRAK
Potensi perikanan teripang di Indonesia mempunyai prospek yang besar. Namun dengan maraknya penangkapan menjadikan spesies teripang ini menjadi langka. Usaha-usaha restocking terus dilakukan untuk mengatasi kelangkaan sumberdaya teripang yang terjadi di Indonesia, salah satu bentuk usaha pengembalian populasi teripang adalah reproduksi secara aseksual (fission atau pembelahan). Teknik pengembangbiakan secara aseksual meliputi pemutusan badan teripang yang merupakan proses penyembuhan dan regenerasi menjadi individu yang baru. Hasil pengembangbiakan aseksual pada berbagai ukuran waring di laut tidak berpengaruh terhadap pola pertumbuhan teripang keling, Holothuria atra. Individu teripang baru hasil pembelahan mampu beradaptasi dengan lingkungannya dengan tingkat sintasan yang tinggi. Namun, perlu dilakukan penelitian lebih lanjut guna memperoleh teknik pengembangbiakan secara aseksual yang lebih optimal.
\end{abstract}

KATAKUNCl: pengembangbiakan aseksual, teripang keling, Holothuria atra

\section{PENDAHULUAN}

Potensi teripang tangkap di Indonesia dinilai cukup besar, yaitu 3.517 ton pada tahun 2001 (DKP, 2004). Usaha perikanan teripang di Indonesia mempunyai tingkat pengusahaan yang intensif. Nusa Tenggara Barat sebagai salah satu contoh wilayah yang memiliki potensi penghasil teripang yaitu $15.500 \mathrm{~kg} / \mathrm{ha}$ pada tahun 2004 , namun dengan maraknya penangkapan teripang yang terjadi menjadikan teripang ini menjadi langka. Penangkapan teripang yang terus-menerus dan cenderung tidak selektif sangat berpengaruh terhadap ketersediaan sumberdaya alam. Kondisi yang ada sekarang hanya dapat diatasi dengan kegiatan budidaya yang terkendali dan ramah lingkungan (BBL, 2003) dan salah satu usaha pengelolaan teripang yaitu melalui stock enhancement dengan menebarkan bibit ke habitat tempat hidupnya (Darsono, 1994). Usaha-usaha restocking terus dilakukan untuk mengatasi kelangkaan sumberdaya teripang yang terjadi di Indonesia, salah satu bentuk usaha pengembalian populasi adalah reproduksi secara aseksual (fission atau pembelahan) pada teripang keling, Holothuria atra. Fission adalah membagi satu individu besar menjadi dua individu yang kecil-kecil.

Habitat teripang adalah ekosistem terumbu karang dan ekosistem lamun, mulai dari zona intertidal sampai dengan kedalaman $20 \mathrm{~m}$. Pada umumnya teripang menyukai perairan yang bersih dan jernih dengan salinitas berkisar 30-33 ppt, dasar berpasir halus dengan tanaman pelindung (jenis-jenis lamun), terlindung dari hempasan ombak, dan lingkungan hidupnya kaya akan kandungan detritus (Aziz, 1997). Purwati (2002) menyatakan dari sekitar 10 jenis teripang yang fisiparus (melakukan reproduksi aseksual melalui fission), hanya 3 spesies yang memiliki nilai jual yaitu Holothuria atra, Holothuria leucospilota, dan Stichopus chloronotus. Hasil pengamatan

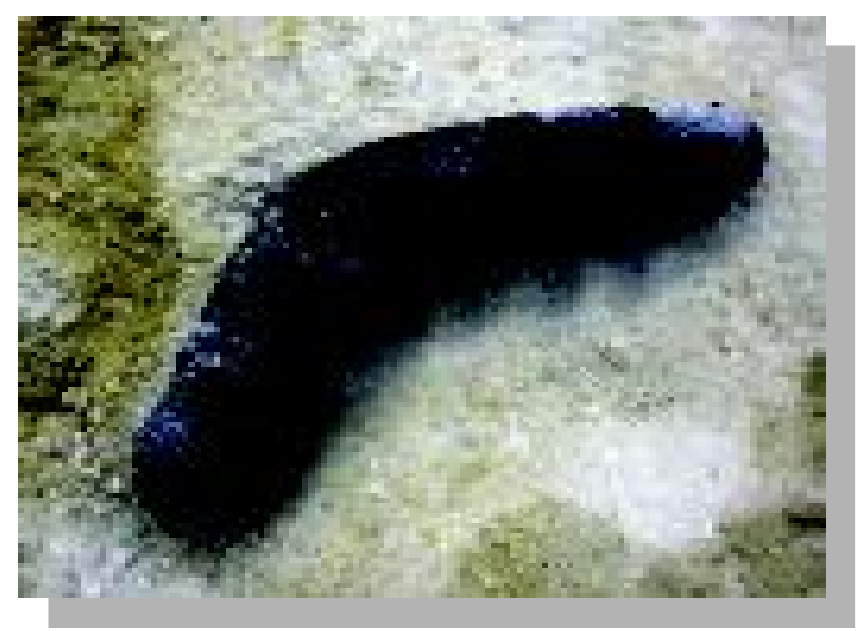

Gambar 1. Teripang keling, Holothuria Atra (www.fobi.web.id) 
Aziz (1995) teripang keling atau teripang batu keling (Gambar 1) memiliki badan licin berwarna hitam sehingga mudah dikenal dan seringkali menjadi spesies yang dominan dalam suatu ekosistem.

\section{BAHAN DAN METODE}

Percobaan dan pengamatan tentang pengembangbiakan aseksual teripang keling (Holothuria atra) dilaksanakan pada bulan Desember 2010 hingga Februari 2011, bertempat di Kampung Manyaifun, Raja Ampat, Papua Barat.

\section{Metode Pengamatan Pengembangbiakan Aseksual}

Tahapan proses pengembangbiakan aseksual yang dilakukan meliputi pemutusan badan teripang dan penyembuhan. Pada penelitian ini dilakukan percobaan dengan perlakuan ukuran waring dengan mesh size $3 \mathrm{~mm}$; $6 \mathrm{~mm}$, dan $9 \mathrm{~mm}$, di mana lokasi pemeliharaan dilakukan di laut.

\section{Pengadaan Teripang}

Teripang yang digunakan sebagai hewan pengamatan adalah teripang keling. Prosedur pencariannya adalah sebagai berikut:

1. Teripang diambil langsung menggunakan tangan kosong dengan bantuan masker dan snorkel.

2. Teripang yang sudah ditangkap ditampung dalam waring sebelum dibawa ke tempat pemeliharaan.

\section{Teknik Pengikatan Teripang}

Teripang diikat dengan jarak pengikatan 33\%atau 1/3 dari bagian anterior. Prosedur kerja pengikatan teripang adalah sebagai berikut:

1. Teripang keling (Holothuria atra) dimasukkan dalam wadah baskom berisi air.

2. Masing-masing wadah diisi satu ekor teripang sehat dan satu buah karet pentil sepeda.

3. Teripang diikat dengan karet pentil sepeda dengan jarak ikat $\pm 33 \%$ dari bagian mulut (anterior).

4. Ikatan diusahakan kuat dan sekencang mungkin untuk menghindari terlepasnya karet dari badan teripang.

\section{Pengukuran Pertumbuhan Panjang dan Bobot Badan}

Prosedur kerjanya adalah sebagai berikut:

1. Kotak pembiakan aseksual dikeluarkan dari dalam air.

2. Waring dibuka dan teripang dikeluarkan dari dalam kotak, diamati apakah teripang sudah mulai putus atau belum, ada atau tidaknya usus yang melekat, terlepas atau terburai.
3. Dari dalam kotak pembiakan, teripang dipindahkan ke dalam wadah sementara (baskom).

4. Teripang diukur dengan penggaris pada bagian kepala dan ekor yang sudah terpisah, dijulurkan ke seluruh bagian kepala/ekor (dari ujung kepala/ekor sampai bagian yang terputus).

5. Angka yang tertera pada penggaris merupakan panjang dari bagian kepala/ekor teripang dan hasil pengukuran kemudian dicatat.

6. Sebelum dilakukan penimbangan bobot, hal yang dilakukan adalah membolak-balikkan badan teripang, agar otot-otot teripang dapat berkontraksi sehingga teripang mengeras/menjadi kaku.

7. Teripang yang sudah mengeras, pada bagian kepala dan ekornya ditutup dengan jari, agar teripang tidak menyemburkan air yang berada dalam badannya.

8. Teripang diletakkan dalam timbangan dan angka yang tertera pada timbangan merupakan bobot dari bagian kepala/ekor teripang. Hasil pengukuran kemudian dicatat.

\section{HASIL DAN BAHASAN}

\section{Pengadaan Teripang}

Teripang yang digunakan sebagai hewan uji berasal dari perairan Kampung Manyaifun, Raja Ampat. Dalam memperoleh teripang tersebut tidak dibutuhkan alat tangkap khusus, namun hanya dibutuhkan alat bantu selam (masker dan snorkel) dan kantong yang terbuat dari waring mesh size $2 \mathrm{~mm}$. Setelah penyelam mencapai dasar perairan dan menemukan teripang, penyelam langsung mengambilnya dan ditampung dalam kantong waring, hal ini didukung oleh Nuraini et al. (1990), di mana pada perairan yang dangkal seperti padang lamun dan rataan terumbu karang dengan kedalaman kurang dari $2 \mathrm{~m}$ penangkapan dilakukan dengan cara memungut (tanpa bantuan alat).

\section{Pengembangbiakan Aseksual}

Pengikatan atau pembelahan secara buatan pada teripang bertujuan untuk membantu proses pembelahan. Proses pengikatan dilakukan secara cepat dan kencang sehingga teripang tidak mengalami kematian. Pengikatan teripang dilakukan dengan jarak pengikatan $1 / 3$ dari bagian badannya, dimulai dari bagian kepala teripang. Bahan yang digunakan sebagai pengikat teripang terbuat dari karet pentil sepeda, karena karet pentil sepeda tidak menyebabkan luka parut pada badan teripang, sehingga mempermudah proses penyembuhan. Hal ini sesuai dengan pendapat Purwati \& Dwiono (2005), diketahui 
bahwa karet pentil sepeda lebih baik, fleksibel, dan tidak berbahaya terhadap kulit teripang uji.

\section{Regenerasi Individu Teripang Baru}

\section{Bobot Rata-Rata Kepala (Anterior-Posterior) Setelah Pemutusan Badan}

Berdasarkan hasil pengukuran bobot rata-rata kepala pada masing-masing waring memiliki perbedaan. Hal ini terlihat pada waring mesh size $3 \mathrm{~mm}$, bobot awal kepala minggu pertama adalah $61,7 \mathrm{~g}$ dan setelah mengalami masa pemeliharaan selama 12 minggu bobot rata-rata menjadi $49 \mathrm{~g}$. Pada waring mesh size $6 \mathrm{~mm}$ bobot ratarata kepala adalah $68,0 \mathrm{~g}$ dan setelah 12 minggu menjadi 73,66 g; pertambahan bobot yang sama terjadi pada waring mesh size $9 \mathrm{~mm}$, bobot awal pada minggu pertama sebesar 49,16 g dan setelah 12 minggu menjadi $56,88 \mathrm{~g}$. Untuk lebih jelasnya dapat dilihat pada Gambar 2.

Grafik pada Gambar 2 menunjukkan bahwa pertumbuhan pada waring mesh size $3 \mathrm{~mm}$ dari setiap minggunya tidak mengalami perubahan yang signifikan. Hal ini dapat dilihat dari minggu pertama sampai minggu kelima masa pemeliharaan terjadi penurunan, dan setelah minggu kelima sampai dengan minggu ke-12 pertumbuhan relatif stabil. Hal demikian dikarenakan pada minggu pertama hingga minggu kelima merupakan masa penyembuhan dan penutupan luka, sehingga pertumbuhan menjadi relatif lambat. Sama halnya dengan waring mesh size $6 \mathrm{~mm}$, pada minggu kedua bobot rata-rata bertambah namun turun kembali di minggu ketiga. Sedangkan minggu ketiga sampai dengan minggu ke-12 bobot ratarata teripang relatif stabil. Bobot teripang pada waring mesh size $9 \mathrm{~mm}$ terus mengalami peningkatan tiap minggunya meskipun tidak signifikan. Pada pertumbuhannya, bagian anterior mengalami proses pemutusan

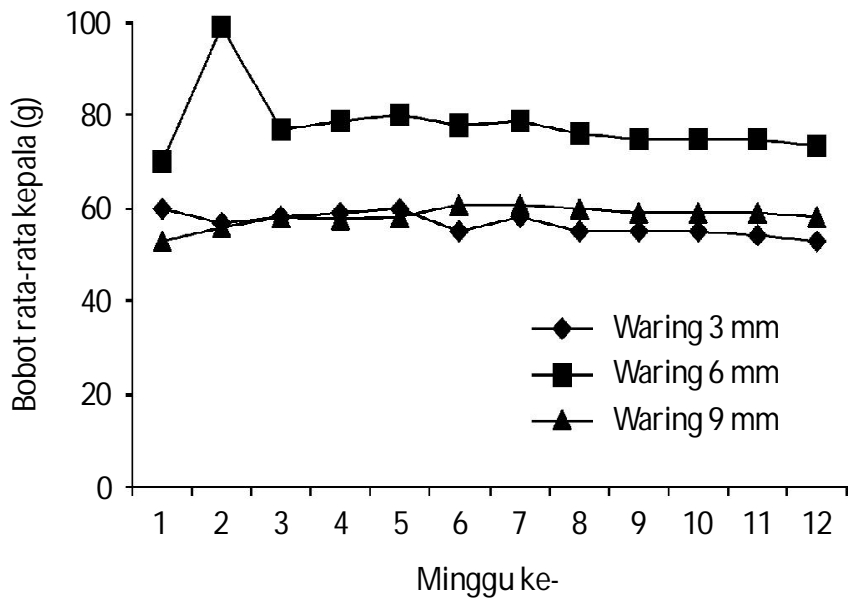

Gambar 2. Bobot rata-rata kepala (anterior-posterior) dan penyerapan/pengeluaran kembali organ dalam yang masih tersisa.

\section{Bobot Rata-Rata Ekor (Posterior-Anterior)}

Individu dalam waring dengan mesh size $3 \mathrm{~mm}, 6 \mathrm{~mm}$, dan $9 \mathrm{~mm}$ secara keseluruhan mengalami perubahan bobot ekor pada setiap minggunya. Berdasarkan hasil pengukuran bobot rata-rata ekor pada masing-masing waring memiliki perbedaan. Hal ini terlihat dari pengukuran pada waring mesh size $3 \mathrm{~mm}$, minggu pertama bobot ekor mencapai $192,50 \mathrm{~g}$ dan setelah masa pemeliharaan selama 12 minggu menjadi $135,0 \mathrm{~g}$. Pada waring mesh size $6 \mathrm{~mm}$ bobot ekor di minggu pertama adalah 158,12 g dan setelah 12 minggu menjadi 119,0 g. Berbeda halnya dengan waring mesh size $9 \mathrm{~mm}$, bobot ekor pada minggu pertama sebesar 73,00 $\mathrm{g}$ dan setelah masa pemeliharaan selama tujuh minggu mencapai $69,56 \mathrm{~g}$. Bobot rata-rata ekor (posterior-anterior) dapat dilihat pada Gambar 3.

Gambar 3 menunjukkan bahwa pada waring mesh size $3 \mathrm{~mm}$ terjadi penurunan pada setiap minggunya. Hal ini disebabkan pada periode ini ekor teripang mengalami proses penyembuhan dan penutupan luka. Bobot ekor pada waring mesh size $6 \mathrm{~mm}$ menurun pada minggu kedua dan setelah minggu ketujuh hingga minggu ke-12 bobot ekor rata-rata relatif stabil. Pada waring mesh size $9 \mathrm{~mm}$ tidak terjadi kenaikan bobot yang berarti dan pada minggu kedelapan bobot rata-rata stabil. Secara umum penurunan bobot rata-rata ekor yang terjadi disebabkan terjadinya proses penutupan luka.

\section{Panjang Rata-Rata Kepala (Anterior-Posterior) Setelah Pemutusan Badan}

Berdasarkan hasil pengukuran panjang rata-rata pada masing-masing waring, diketahui bahwa pada waring mesh

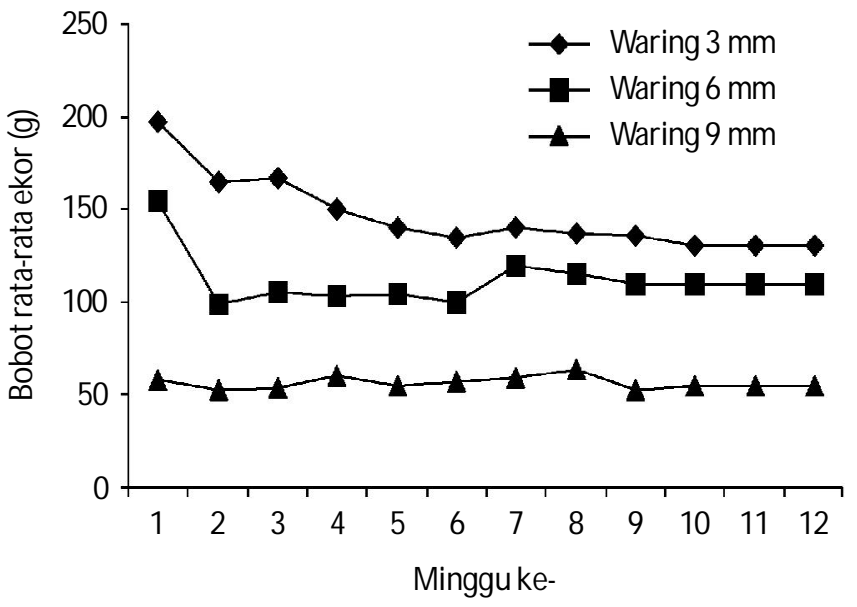

Gambar 3. Bobot rata-rata ekor (posterior-anterior) 
size $3 \mathrm{~mm}$ di minggu pertama mempunyai panjang awal $5,34 \mathrm{~cm}$; dan setelah 12 minggu masa pemeliharaan panjang rata-rata mencapai $11,96 \mathrm{~cm}$. Pada waring mesh size $6 \mathrm{~mm}$, panjang awal sebesar $8,53 \mathrm{~cm}$ dan setelah 12 minggu menjadi $16,03 \mathrm{~cm}$. Sedangkan panjang awal kepala pada waring mesh size $9 \mathrm{~mm}$ saat minggu pertama adalah $9,05 \mathrm{~cm}$ dan setelah 12 minggu mencapai $13,35 \mathrm{~cm}$ seperti terlihat pada Gambar 4.

Gambar 4 menunjukkan pertumbuhan panjang kepala pada masing-masing waring. Pada waring mesh size $3 \mathrm{~mm}$ terlihat terjadi kenaikan panjang pada minggu keempat dan turun pada minggu kelima. Pada waring mesh size $6 \mathrm{~mm}$ terjadi kenaikan panjang rata-rata yang signifikan pada minggu keempat namun kembali mengalami penurunan di minggu kelima. Sedangkan pada waring mesh size $9 \mathrm{~mm}$ mengalami penurunan sampai minggu ketiga dan meningkat signifikan sampai minggu keempat dan relatfi stabil hingga akhir pemeliharaan (12 minggu). Penurunan pertumbuhan merupakan indikasi bahwa teripang dalam masa penyembuhan (penutupan luka), sedangkan peningkatan yang terjadi mengindikasikan teripang dalam tahap regenerasi kembali.

\section{Panjang Rata-Rata Ekor (Posterior-Anterior) Setelah Pemutusan Badan}

Berdasarkan hasil pengukuran panjang rata-rata ekor diketahui bahwa pada setiap waring, panjang ekor teripang mengalami perubahan secara fluktuatif. Pada waring mesh size $3 \mathrm{~mm}$ di minggu pertama mempunyai panjang ekor sebesar $11,66 \mathrm{~cm}$ dan pada minggu ke-12 meningkat menjadi 29,89 cm. Waring mesh size $6 \mathrm{~mm}$ mempunyai panjang ekor sebesar $13,16 \mathrm{~cm}$ pada minggu pertama dan setelah 12 minggu masa pemeliharaan mencapai 28,65 cm. Sedangkan waring mesh size $9 \mathrm{~mm}$ panjang teripang pada minggu pertama sebesar $8,89 \mathrm{~cm}$

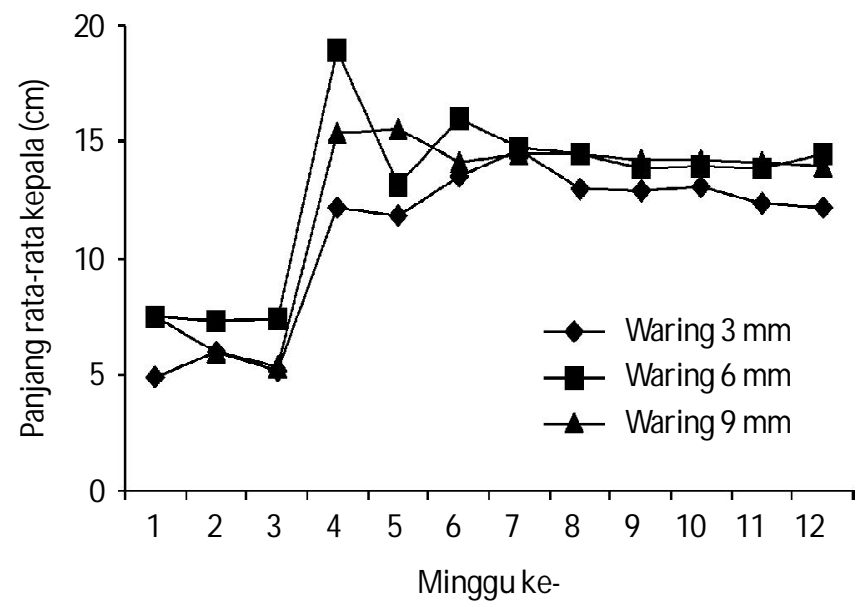

Gambar 4. Panjang rata-rata kepala (anterior-posterior) dan setelah minggu ke-12 menjadi sebesar 19,95 cm (Gambar 5).

Pada waring mesh size $3 \mathrm{~mm}$, di awal masa pemeliharaan tidak terjadi peningkatan pertumbuhan yang signifikan, namun pada minggu ketiga terjadi pertambahan panjang ekor. Penurunan terjadi pada minggu keenam kemudian meningkat lagi di minggu ketujuh, namun dari minggu kedelapan hingga akhir masa pemeliharaan fluktuasi pertumbuhan tidak signifikan. Pada waring mesh size $6 \mathrm{~mm}$, peningkatan terjadi pada minggu keempat dan mengalami penurunan pada minggu keenam. Panjang rata-rata tertinggi dicapai pada minggu kedelapan yaitu $34,89 \mathrm{~cm}$; kemudian menurun hingga 29,69 cm di akhir pemeliharaan. Pada waring mesh size $9 \mathrm{~mm}$ menunjukkan bahwa pada minggu ketiga hingga kelima tidak terjadi fluktuasi panjang ekor rata-rata (relatif statis), namun pada minggu keenam terjadi penurunan dan meningkat kembali pada minggu ketujuh serta relatif stabil hingga akhir pemeliharaan. Terjadinya penambahan panjang rata-rata umumnya terjadi pada awal pemeliharaan, dikarenakan pada awal pemeliharaan merupakan proses penyembuhan dan penutupan luka di mana otot-otot badan teripang tidak berkontraksi sehingga ukurannya semakin panjang. Sesuai dengan pendapat Purwati \& Dwiono (2005) di mana proses pembelahan terjadi dalam dua sampai tiga minggu setelah proses pembelahan, selain itu, dalam waktu dua hari setelah masa pemutusan badan, pertumbuhan pada individu baru tetap dan bagian yang terputus sudah mulai menutup. Hasil pengamatan Darsono (1999) menyebutkan pada fase pembelahan (fission) teripang akan mencari tempat berlindung dan berkontraksi. Setelah putus, maka terpisah bagian anterior $(A)$ dan posterior $(\mathrm{P})$ di mana tanda-tanda akan terjadinya pembelahan dapat diketahui baik dari luar ataupun dalam badan. Tanda luar terlihat

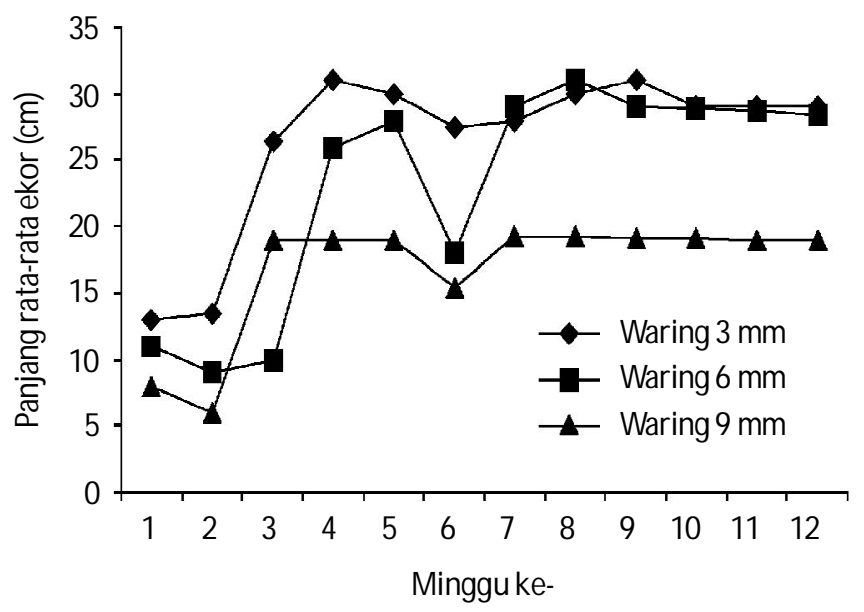

Gambar 5. Panjang rata-rata ekor (posterior-anterior) 
pada bagian dinding badan (integument) yang berkontraksi atau membentuk kerutan seperti cincin (ring) pada badan, sedang tanda dalam terlihat adanya kerutan pada otot longitudinal pada titik di mana akan terjadi pembelahan. Sedangkan pada fase pemulihan diri (regenerasi) setelah pembelahan terjadi, bagian A hanya memiliki sedikit organ terdiri atas mulut dengan tentakel (appendages), gonad, dan bagian dari usus (intestine). Aktivitas makan mulai lebih cepat sebelum seluruh organ tersebut beregenerasi semula. Adapun pada bagian $\mathrm{P}$ umumnya sebagian besar organ masih ada. Sedangkan Purwati (2001) menyatakan bahwa recruitment melalui fission menghasilkan individu-individu baru yang telah beradaptasi dengan lingkungannya, terbebas dari periode kritis yang dialami semasa larva dan yuwana, dan terhindar dari kemungkinan terbawa arus.

Namun perlu diperhatikan, bahwa pengukuran panjang rata-rata tidak dapat digunakan sebagai acuan dalam pengamatan regenerasi teripang. Hal tersebut dikarenakan panjang badan teripang sewaktu-waktu dapat berubah (memanjang atau memendek) sesuai kondisi lingkungan. Selain itu, material yang terdapat dalam badan teripang sebagian besar terdiri atas air yang dapat membentuk badan teripang setiap saat.

\section{Tingkat Sintasan (SR)}

Teripang yang mengalami fission atau pembelahan mempunyai tingkat sintasan yang cukup tinggi. Pada masing-masing waring mesh size $(3 \mathrm{~mm}, 6 \mathrm{~mm}$, dan 9 $\mathrm{mm}$ ) mempunyai tingkat sintasan mencapai $100 \%$ Hal ini membuktikan bahwa perlakuan perbedaan ukuran waring di laut tidak mempengaruhi tingkat sintasan individu teripang baru.

\section{KESIMPULAN DAN SARAN}

\section{Kesimpulan}

Pengembangbiakan secara aseksual dalam berbagai ukuran waring tidak mempengaruhi pertumbuhan teripang keling, Holothuria atra. Individu teripang setelah mengalami fission atau pembelahan mampu beradaptasi dengan lingkungannya, sehingga tingkat sintasan pada setiap perlakuan yang dibudidayakan di laut dapat mencapai $100 \%$

\section{Saran}

Perlu dilakukan penelitian lebih lanjut mengenai pengembangbiakan aseksual dan proses regenerasinya sehingga dapat memperoleh hasil yang optimal.

\section{DAFTAR ACUAN}

Aziz, A. 1995. Beberapa Catatan Tentang Teripang Bangsa Aspidochirotida. Oseana, XX(4): 11-23.

Aziz, A. 1997. Status Penelitian Teripang Komersial di Indonesia. Oseana, XXII(1): 9-19.

Balai Budidaya Laut. 2003. Pembenihan Teripang Pasir (Holothuria scraba). Direktorat Jenderal Perikanan Budidaya. Departemen Kelautan dan Perikanan Lampung, $54 \mathrm{hlm}$.

Darsono, P. 1994. Usaha Pembenihan untuk Pelestarian Sumberdaya Teripang. Oseana, XIX(4): 13-21.

Darsono, P. 1999. Reproduksi A-Seksual Pada Teripang. Oseana, XXIV(2): 1-11.

Departemen Kelautan dan Perikanan. 2004. Pedoman Monitoring Teripang. Direktorat Konservasi dan Taman Nasional Laut. Direktorat Jenderal Pesisir dan Pulau-Pulau Kecil. Departemen Kelautan dan Perikanan Republik Indonesia. Jakarta, $30 \mathrm{hlm}$.

Laxminarayana, A. 2006. Asexual Repruduction By Induced Transverse Fission In The Sea Cucumber Bohadschia marmorata and Holothuria atra. SPC Beche-de-mer Information Bulletin, 23 Februari, p. 35.

Purwati, P. 2001. Ekspresi Fission dan Konsekuensinya Bagi Populasi Fisiparus Holothuroidea (Echinodermata). Oseana, XXVI(4): 33-41.

Purwati, P. 2002. Pemulihan Populasi Teripang Melalui Fision, Mungkinkah? Oseana, XXVII(1): 19-25.

Purwati, P. \& Dwiono, S.A.P. 2005. Fission Inducement In Indonesian Holothurians. SPC Beche-de-mer Information Bulletin, 22 Juli, p. 11.

www.fobi. web.id. Serial online 19 Februari 2008. 